\title{
The Research of Concrete Pile Material in Mechanical Property
}

\author{
Ximing ZHANG ${ }^{1, \text { a }}$, Shupin NING ${ }^{2, b}$, Fan ZHANG $^{3, c}$, Linjie $\mathrm{ZHAO}^{4, \mathrm{~d}}$ \\ Municipal \& Environmental Engineering College,Jilin Jian zhu University, Jilin,Changchun, \\ China
}

Corresponding author:E-mail:Zhangxm1999@163.com

\begin{abstract}
Keywords: concrete pile, mechanical property, ratio value, heat exchange
Abstract: Concrete pile technology is a new technology to improve people's living environment by extracting underground potential of pile foundation. This kind of technology requires good heat transfer effect and invariable mechanical performance of concrete pile. The heat storage performance of concrete pile is the key to ensure its heat storage and heat release capacity. The technology is to bury the heat exchanger tube in the pile foundation of building. It transmits the solar radiation and heat in spring, summer and autumn to the earth's soil through the heat exchange tube and extracts the stored heat energy in winter, so as to save heat and keep the continuous cycle of heat. In this paper, the material ratio of concrete is analyzed on the basis of mechanical properties. The optimum material ratio of concrete pile is obtained.
\end{abstract}

\section{Introduction}

The heat transfer pipe installed in the pile foundation of the building by the concrete pile technology can transfer the heat collected from the solar radiation energy to the soil. The working principle of solar energy and other resources in the circulation of heat storage and heat recovery is shown in Fig.1. The pile foundation of the building mainly bears the main load of the building, but the heat transfer tube is buried in the pile foundation which leads to the weakening of the bearing capacity of the concrete pile. In this paper, the method of orthogonal test is used to verify the mechanical properties of concrete pile materials. By changing the percentage content of several main materials affecting the compressive capacity of concrete piles, the compressive test of 9 groups of different materials was carried out and the optimum ratio of mechanical properties was obtained. 


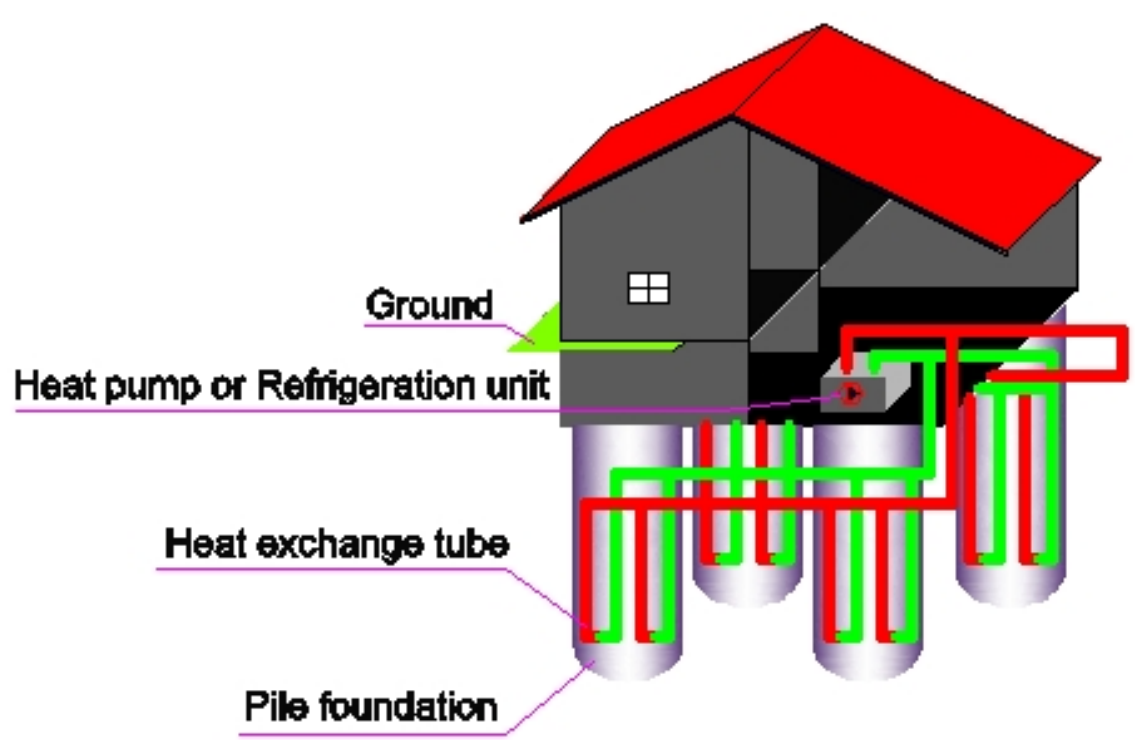

Fig .1 working principle of concrete heat storage pile

\section{Concrete pile material}

(1) Concrete: According to test needs, composite Portland cement as cementitious material for concrete pile has better economic and mechanical properties. Therefore, cementitious material is chosen for local Ding Lu brand cement, and its strength grade is 32.5, GB175-2007.

(2) Fine aggregate: Select fine aggregate moisture content:5\%, density is $2.55 \times 103 \mathrm{Kg} / \mathrm{m}^{3}$.

(3) Coarse aggregate: Strict selection of coarse aggregate is required to meet the requirements of high strength, uniform volume and no special shape. Basalt sand is chosen as coarse aggregate with uniform particle size, no active silicon, no flake and needle shape. The density of sand is $2.65 \times 10^{3} \mathrm{~kg} / \mathrm{m}^{3}$

(4) Fiber: Adding fiber to increase the strength of concrete pile. Steel fiber is selected as reinforcing fiber.

(5) Thermal storage materials: Copper slag and graphite have better thermal conductivity, graphite also has better energy saving and environmental protection performance. The density of waste copper slag selected in this experiment is $3.3 \mathrm{~g} / \mathrm{cm}$, Origin: Shanxi, China. Graphite density $1.8 \mathrm{~g} / \mathrm{cm}^{3}$, Origin: Tianjin, China.

\section{Verification test of mechanical properties of concrete}

Experimental method. This test is mainly to verify the compressive capacity of concrete materials. Graphite content, fiber content, waste copper slag amount and water-binder ratio are the main factors affecting the mechanics of concrete pile ${ }^{[1]}$. This experiment redistributes the original ratio and compares it with the original ratio ${ }^{[2]}$. In order to improve the original ratio and optimize the ratio value. According to the percentage change of graphite, steel fiber and copper slag, the orthogonal test combination was obtained.

The research group conducted a compressive strength test on a $100 \mathrm{~mm} \times 100 \mathrm{~mm} \times 100 \mathrm{~mm}$ $\mathrm{C} 30$ concrete block. Each time $10 \mathrm{Kg}$ ingredients are taken, the cement material mass is $1.93 \mathrm{Kg}$ and the volume is $1.19 \mathrm{~m}^{3}$; the fine aggregate mass is $2.67 \mathrm{Kg}$ and the volume is $2.05 \mathrm{~m}^{3}$; the coarse aggregate mass is $4.51 \mathrm{Kg}$, and the volume is $3.38 \mathrm{~m}^{3}$; The mass is $0.89 \mathrm{Kg}$ and the volume is $1.78 \mathrm{~m}^{3}$. 
Specific quality values are shown in Table 2-1.

Table 2-1 Factor Level Quality Table

\begin{tabular}{c|c|c|c}
\hline Factor & $\begin{array}{c}\text { Copper slag } \\
(\mathrm{g})\end{array}$ & $\begin{array}{c}\text { Steel fibre } \\
(\mathrm{g})\end{array}$ & $\begin{array}{c}\text { Graphite } \\
(\mathrm{g})\end{array}$ \\
\hline 1 & 98.4 & 186.3 & 2.1 \\
\hline 2 & 131.2 & 372.6 & 4.2 \\
\hline 3 & 196.8 & 745.2 & 8.4 \\
\hline
\end{tabular}

Experimental procedure. The concrete samples of $100 \mathrm{~mm} \times 100 \mathrm{~mm} \times 100 \mathrm{~mm}$ are made by our research group, in which every 3 pieces are a small group. In this test, 9 sets of concrete test blocks were respectively taken out of 9 sets of concrete test pieces with different material mix proportions in order to test the compressive strength of the mix ratio of different materials. The experimental values on day 3, day 7 and day 28 were selected as finishing objects. The tests used were domestic instruments and equipment, including concrete pressure testers, electronic scales, and standard maintenance boxes. Table 2-2 shows the test quality table.

(1) Remove the test block from the curing box and check the appearance of the test block.

(2) Loading the test block, take the speed $0.5 \sim 0.8 \mathrm{MPa} / \mathrm{s}$.

(3) The test result selection error: Error within $15 \%$.

Table 2-2 Orthogonal test quality table

\begin{tabular}{c|c|c|c|c|c|c|c}
\hline $\begin{array}{c}\text { Column } \\
\text { number }\end{array}$ & $\begin{array}{c}\text { Graphite } \\
(\mathrm{g})\end{array}$ & $\begin{array}{c}\text { Steel } \\
\text { fiber } \\
(\mathrm{g})\end{array}$ & $\begin{array}{c}\text { Cooper } \\
\text { slag } \\
(\mathrm{g})\end{array}$ & $\begin{array}{c}\text { Coarse } \\
\text { aggregate } \\
(\mathrm{Kg})\end{array}$ & $\begin{array}{c}\text { Fine } \\
\text { aggregate } \\
(\mathrm{Kg})\end{array}$ & $\begin{array}{c}\text { Cementing } \\
\text { material } \\
(\mathrm{Kg})\end{array}$ & $\begin{array}{c}\text { Water } \\
(\mathrm{Kg})\end{array}$ \\
\hline 1 & 2.1 & 186.3 & 98.4 & 4.51 & 2.570 & 1.93 & 0.89 \\
\hline 2 & 4.2 & 186.3 & 131.2 & 4.51 & 2.535 & 1.93 & 0.89 \\
\hline 3 & 8.4 & 186.3 & 196.8 & 4.51 & 2.465 & 1.93 & 0.89 \\
\hline 4 & 2.1 & 372.6 & 131.2 & 4.51 & 2.351 & 1.93 & 0.89 \\
\hline 5 & 4.2 & 372.6 & 196.8 & 4.51 & 2.283 & 1.93 & 0.89 \\
\hline 7 & 8.4 & 372.6 & 98.4 & 4.51 & 2.377 & 1.93 & 0.89 \\
\hline 8 & 2.1 & 745.2 & 196.8 & 4.51 & 1.913 & 1.93 & 0.89 \\
\hline 9 & 4.2 & 745.2 & 98.4 & 4.51 & 2.009 & 1.93 & 0.89 \\
\hline & 8.4 & 745.2 & 131.2 & 4.51 & 1.972 & 1.93 & 0.89 \\
\hline
\end{tabular}

Experimental result. The data obtained from the test was converted into standard test block $(150 \mathrm{~mm} \times 150 \mathrm{~mm} \times 150 \mathrm{~mm})$ data, and each item was multiplied by a correction value of 0.95 . According to the orthogonal test method, the distribution table was designed and the concrete test 
block was made. After maintenance, the standard test of the test block was started. Table 2-3 is the recorded test data.

Table 2-3 Test data

\begin{tabular}{c|c|c|c}
\hline $\begin{array}{c}\text { Column } \\
\text { number }\end{array}$ & $\begin{array}{c}3 \text { days pressure } \\
(\mathrm{M} \mathrm{Pa})\end{array}$ & $\begin{array}{c}7 \text { days pressure } \\
(\mathrm{M} \mathrm{Pa})\end{array}$ & $\begin{array}{c}28 \text { days pressure } \\
(\mathrm{M} \mathrm{Pa})\end{array}$ \\
\hline 1 & 21.198 & 23.492 & 29.246 \\
\hline 2 & 21.096 & 23.791 & 29.493 \\
\hline 4 & 24.502 & 29.164 & 36.317 \\
\hline 5 & 22.254 & 30.655 & 31.044 \\
\hline 6 & 21.439 & 25.744 & 29.323 \\
\hline 8 & 19.982 & 25.119 & 28.853 \\
\hline 9 & 19.229 & 19.627 & 30.730 \\
\hline
\end{tabular}

\section{Conclusion}

With the development and progress of human society, the consumption of primary energy such as coal and petroleum is increasing day by day, which seriously pollutes the environment. As people's awareness of energy conservation and environmental protection continues to increase, many energy-saving and environmental protection technologies have also developed. Ground source heat pump is a new type of technology that uses underground shallow energy. It has the advantages of saving energy and protecting the environment. It has developed more and more. The disadvantages of ground source heat pump technology are also prominent, mainly due to the high construction cost and long construction period. Many scholars and experts at home and abroad have proposed concrete pile technology, which has the advantages of ground source heat pump and makes up for the shortcomings of ground source heat pump. As the technology of concrete piles is to embed heat exchange tubes in the foundations of buildings, the building pile foundations are mainly responsible for the main load of the buildings, resulting in a reduction in the bearing capacity of concrete piles. Therefore, the research on the testing of the mechanical properties of concrete piles is increasingly becoming the focus. In the course of research and application, it is necessary to ensure that the concrete piles have good heat transfer performance and that their mechanical properties remain unchanged. The orthogonal experimental verification method was adopted by our research group. Based on the analysis of the material ratio of concrete to the mechanical properties, the optimum material ratio of the mechanical properties of concrete piles was obtained.

(1) By refining the percentage content of the three kinds of materials, two sets of data with better mechanical properties were obtained, namely the ratio of the third group and the fourth group.

(2) As can be seen from Table 2-3, the third group of proportioning materials had the highest 
compressive value on the 3rd day, reaching $24.502 \mathrm{M} \mathrm{Pa}$, and the highest pressure values for the 7 th and 28th days were the fourth group with the pressure values of $30.655 \mathrm{M} \mathrm{Pa}$ and $40.358 \mathrm{M} \mathrm{Pa}$, respectively.

\section{References}

[1]Chaoming Pang, Honggen Qin. Experimental Design and Nondestructive Testing of Concrete[M]. Beijing: China Building Material Industry Press, 2006. 49-50.

[2]Songying Zhao, Dawei Jiang, Xiaodong Song. Research on the selection of thermal energy storage material for energy piles; Journal of Jilin Architectural and Civil Engineering, 2013(6):32-35. 